\title{
On the High Ionic Conductivity of Solid Solutions of Lithium Sulphate in Hexagonal Sodium Sulphate $\mathrm{Na}_{2} \mathrm{SO}_{4}$ (I)
}

\author{
Arnold Lundén ${ }^{\mathrm{a}}$ and Leif Nilsson ${ }^{\mathrm{b}}$ \\ a Department of Physics and \\ b Monitoring Center for Energy Research, Chalmers University of Technology, S-412 96 Göteborg, \\ Sweden
}

\section{Z. Naturforsch. 50a, 327-328 (1995); received November 15, 1994}

Solid solutions of $\mathrm{Li}_{2} \mathrm{SO}_{4}$ in the high-temperature phase $\mathrm{Na}_{2} \mathrm{SO}_{4}(\mathrm{I})$ have a much higher conductivity than expected. Diffusion and electromigration experiments show that both $\mathrm{Li}^{+}$and $\mathrm{Na}^{+}$ions are very mobile. It is concluded that the $\mathrm{Li}^{+}$ions go into interstitial positions of the type $(1 / 2,0,0)$, while vacancies are created in the $\mathrm{Na}^{+}$lattice.

The high-temperature phase of $\mathrm{Na}_{2} \mathrm{SO}_{4}$ has a high solubility for many other cations. As expected, the addition of di- and trivalent cations causes a pronounced increase of the ionic conductivity [1-4], but this is also the case when $\mathrm{Li}_{2} \mathrm{SO}_{4}$ is added [5, 6]. E.g. at $873 \mathrm{~K}$ the electrical conductivity is $0.002 \mathrm{~S} / \mathrm{cm}$ for pure $\mathrm{Na}_{2} \mathrm{SO}_{4}$ [7], $0.29 \mathrm{~S} / \mathrm{cm}$ for $\mathrm{Li}_{0.5} \mathrm{Na}_{1.5} \mathrm{SO}_{4}[6]$ and $0.08 \mathrm{~S} / \mathrm{cm}$ for $\mathrm{Mg}_{0.25} \mathrm{Na}_{1.5} \mathrm{SO}_{4}$ [4]. Furthermore, an electromigration experiment has been performed for $\mathrm{Li}_{0.4} \mathrm{Na}_{1.6} \mathrm{SO}_{4}$ [8], and the mobility was found to be $55 \%$ higher for $\mathrm{Li}^{+}$than for $\mathrm{Na}^{+}$. Cation diffusion has been studied in $\mathrm{Li}_{0.5} \mathrm{Na}_{1.5} \mathrm{SO}_{4}$ by Bengtzelius [9]: $D(\mathrm{Na})$ was $0.23 \times 10^{-5} \mathrm{~cm}^{2} / \mathrm{s}$ at $803 \mathrm{~K}$ and $0.36 \times 10^{-5} \mathrm{~cm}^{2} / \mathrm{s}$ at $865 \mathrm{~K}$. This corresponds to an activation energy $Q(\mathrm{Na})$ of $0.4 \mathrm{eV}$. It may be fortuitous, but this coincides with the $Q(\mathrm{Na})$ of f.c.c. $\mathrm{Li}_{1.5} \mathrm{Na}_{0.5} \mathrm{SO}_{4}$ and b.c.c. $\mathrm{LiNaSO}_{4}[10]$.

The abovementioned pronounced conductivity-increases are a strong indication that vacancies are created in the $\mathrm{Na}^{+}$lattice not only when aliovalent cations are added, but also when $\mathrm{Li}^{+}$ions are present [11]. It is the purpose of this paper to see whether this is plausible according to $\mathrm{X}$-ray structure data.

$\mathrm{Na}_{2} \mathrm{SO}_{4}(\mathrm{I})$ has the space group $\mathrm{P}_{3} / \mathrm{mmc}[12,13]$ with $a=5.444 \AA, c=7.347 \AA, Z=2$ and $V=188.6 \AA^{3}$ at $693 \mathrm{~K}$. There are two positions for $\mathrm{Na}^{+}$ions, cf. Figure 1. One is on the $c$-axis with coordinates $(0,0,0)$ and $(0,0,1 / 2)$, etc. The other position has coordinates of the type $(1 / 3,2 / 3,3 / 4)$ and $(2 / 3,1 / 3,1 / 4)$, etc. All sodium positions of both types are fully occupied. $S$ is at $(1 / 3,2 / 3,1 / 4)$ and $(2 / 3,1 / 3,3 / 4)$, etc. i.e. they are straightly above or below those Na-positions that are "inside" the unit cell.

Reprint requests to Prof. Dr. A. Lundén.
The confidence is not quite as good concerning the oxygen positions. However, it seems evident that three oxygens are practically in a plane parallel to the $a-a$ plane and rather close to $c=1 / 4$ or $3 / 4$. These oxy-
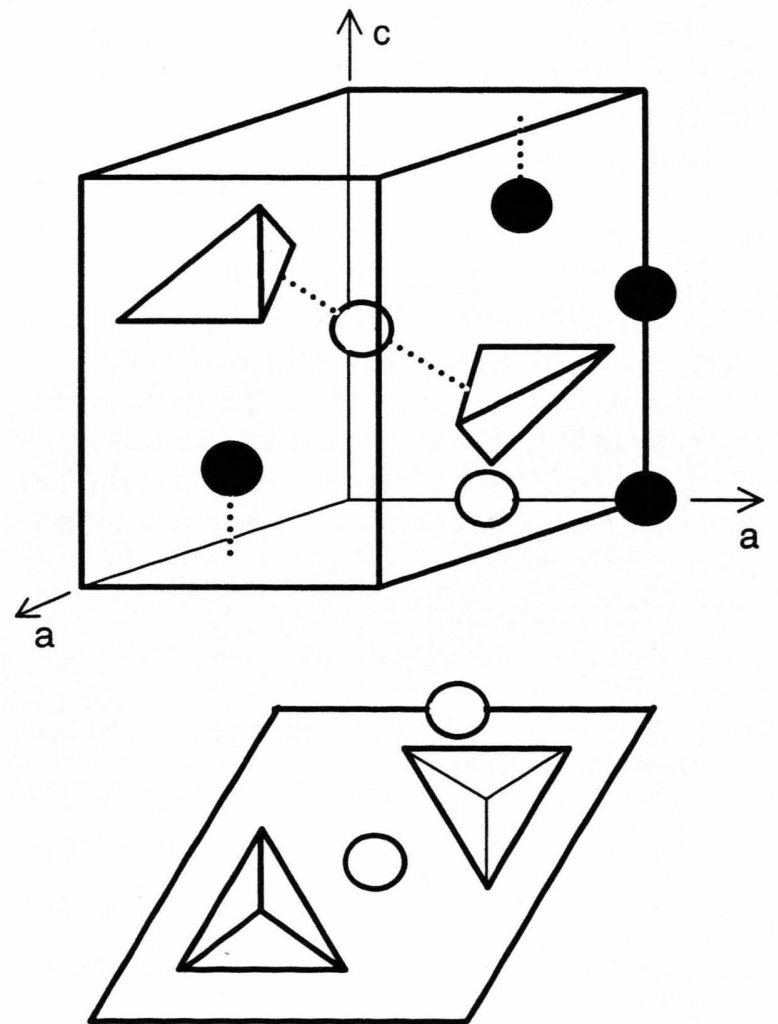

Fig. 1. A schematic representation of the hexagonal unit cell. The sulphate groups are shown as tetrahedrons, sodium ions as filled circles and the proposed interstitial positions as open circles. The sulphates are distributed statistically between "up" and "down" directions. Only a representative number of cation positions is shown. 
gens have their largest vibrational motion in the $c$-direction. According to the most common opinion, two sides of the oxygen triangle are parallel to the $a$-axis of the cell. There is an excess of this type of oxygen positions. They are "mirrored" above or below the plane $c=1 / 4$, and it should be this fact that results in the large vibrational amplitude in the $c$-direction.

The remaining $25 \%$ of the oxygen atoms are close to the threefold symmetry line through the $\mathrm{SO}_{3}$ plane, in parallel with the $c$-axis. The orientation is such that the sulphate ions are equally divided between the directions "up" and "down". It seems reasonable that the top of the tetrahedron usually points in the direction that is not occupied by $\mathrm{Na}$. There is a surplus also of these oxygen positions, with a star-shaped distribution around the symmetry axis.

The average interatomic distances of the structure can be summarized: $\mathrm{Na}-\mathrm{O} 2.79 \AA$ for $\mathrm{Na}$ on the $c$-axis and $3.05 \AA$ inside the unit cell. The expected $\mathrm{Na}-\mathrm{O}$ for 6-coordination is $2.25-2.78 \AA$ [14]. The smallest $\mathrm{Na}-\mathrm{Na}$ becomes $3.64 \AA$.

The only vacant site in the structure seems to be of the type $(1 / 2,0,0)$. There are six such positions of the type $6 \mathrm{~g}$ [14] per unit cell with the coordinates $(1 / 2,0,0)$, $(0,1 / 2,0),(1 / 2,1 / 2,0),(1 / 2,0,1 / 2),(0,1 / 2,1 / 2)$, and $(1 / 2,1 / 2,1 / 2)$. They are all crystallographically equal except for the effects caused by the oxygen disorder. Thus there are in total three vacant positions per formula unit of $\mathrm{SO}_{4}$. These positions are at a reasonable distance to both types of surrounding oxygens. Thus, the distance is abot $2.21-2.50 \AA$ to those four oxygens

[1] H. H. Höfer, W. Eysel, and U. von Alpen, J. Solid State Chem. 36, 365 (1981).

[2] M. S. Kumari, and E. A. Secco, Can. J. Chem. 61, 599 \& 2804 (1983).

[3] W. Eysel, H. H. Höfer, K. L. Keester, and Th. Hahn, Acta Cryst. B 41, 5 (1985).

[4] P. W. S. K. Bandaranayake and B.-E. Mellander, Solid State Ionics 40/41, 31 (1990).

[5] A.-M. Josefson and A. Kvist, Z. Naturforsch. 24a, 466 (1969).

[6] C. N. Wijayasekera and B.-E. Mellander, Radiation Effects and Defects in Solids 119-121, 981 (1991).

[7] M. A. Careem and B.-E. Mellander, Solid State Ionics 15, 327 (1985).

[8] A. Lundén, A. Floberg, and R. Mattsson, Z. Naturforsch. 28a, 1857 (1973).

[9] A. Bengtzelius, unpublished.

[10] A. Lundén, L. Nilsson, and R. Tärneberg, Proc. 4th Int. Symp. on Systems with Fast Ionic Transport, Warsaw, 10-14 May, 1994. Trans. Tech. Publications. which are located in planes lying parallel with the $a-a$ plane. Concerning the other type of oxygens, the distance is about $2.19 \AA$ if the threefold symmetry axis is favourably oriented, i.e. if it is tilted away from the vacant position, but otherwise $1.42 \AA$. The expected $\mathrm{Li}-\mathrm{O}$ distance is $1.86-2.05 \AA$ if 4 -coordinated, or $2.00-2.41 \AA$ if 6 -coordinated [14]. Thus, a possible introduction of $\mathrm{Li}$ in the considered positions should cause a certain tilting of neighbouring $\mathrm{SO}_{4}$ tetrahedrons.

$\mathrm{Na}_{2} \mathrm{SO}_{4}$ (I) is isostructural with the high temperature phases of $\mathrm{Ag}_{2} \mathrm{SO}_{4}, \mathrm{~K}_{2} \mathrm{SO}_{4}, \mathrm{Rb}_{2} \mathrm{SO}_{4}$, and $\mathrm{Cs}_{2} \mathrm{SO}_{4}$. While the solid solubility of $\mathrm{Li}$ is $46.5 \mathrm{~mole} \%$ in $\mathrm{Na}_{2} \mathrm{SO}_{4}$ [15-17], it is $26 \mathrm{~mole} \%$ in $\mathrm{Ag}_{2} \mathrm{SO}_{4}$ [18], 2-3 mole $\%$ in $\mathrm{K}_{2} \mathrm{SO}_{4}[17,19]$ and not detectable (upper limit 2 mole\%) in $\mathrm{Rb}_{2} \mathrm{SO}_{4}$ and $\mathrm{Cs}_{2} \mathrm{SO}_{4}[16,17]$. Thus, a pronounced conductivity enhancement due to doping with lithium can be expected to occur also in silver and potassium sulphate.

As said in the introductory section the activation energy for diffusion of sodium ions is nearly the same in $\mathrm{Na}_{2} \mathrm{SO}_{4}(\mathrm{I})$ as it is in the two cubic phases $\mathrm{Li}_{2} \mathrm{SO}_{4}$ and $\mathrm{LiNaSO}_{4}$. A discussion of ion transport mechanisms in these two cubic phases will appear elsewhere [20].

\section{Acknowledgement}

This study has been supported by "Ollie and Elof Ericssons Stiftelse".

[11] A. Lundén, in Fast Ion Transport in Solids, eds. B. Scrosati, A. Magistris, C. M. Mari, and G. Mariotto, NATO ASI Series E, 250, Kluwer Acad. Publ., Dordrecht 1993, p. 181.

[12] W. Eysel, H. H. Höfer, K. L. Keester, and Th. Hahn, Acta Cryst. B 41, 5 (1985).

[13] H. Naruse, K. Tanaka, H. Morikawa, F. Marumo, and B. N. Mehrotra, Acta Cryst. B 43, 143 (1987).

[14] International Tables for X-ray Crystallography, Vol. I-III, Kynoch Press, Birmingham 1968.

[15] L.-I. Staffansson, Acta Chem. Scand. 26, 2150 (1972).

[16] K. Schroeder, A. Kvist, and H. Ljungmark, Z. Naturforsch. 27 a, 1252 (1972).

[17] K. Schroeder, Thesis, University of Gothenburg, 1975.

[18] H. A. Øye, Thesis, Technical University of Norway, Trondheim 1963.

[19] K. Schroeder and A. Kvist, Z. Naturforsch. 24a, 844 (1969).

[20] R. Tärneberg and A. Lundén, to be published in Solid State Ionics. 